\title{
EFEKTIVITAS PENDEKATAN REALISTIC MATHEMATICS EDUCATION (RME) BERBANTUAN APLIKASI EDMODO TERHADAP KEMAMPUAN PEMECAHAN MASALAH MATEMATIS SISWA
}

\author{
Fitri Sulastri $^{1)}$, Runisah ${ }^{2)}$, Denni Ismunandar ${ }^{3)}$ \\ ${ }^{1,2,3)}$ Program Studi Pendidikan Matematika, Universitas Wiralodra, Jalan Ir. H. Juanda \\ Indramayu \\ fitrisulastri2205@yahoo.com ${ }^{1)}$, runisah 69@yahoo.co.id ${ }^{2)}$, denni.ismunandar@unwir.ac.id ${ }^{3)}$
}

Received:
06/01/2021
Accepted:
09/01/2021
Published:
21/01/2021

\begin{abstract}
The ability to solve problems, especially in mathematics, is needed by students. The reality in the field shows that the students' mathematical problem solving abilities are still low. One of the efforts to overcome this problem is by applying the Realistic Mathematics Education (RME) approach with the aid of Edmodo application. The research objective was to determine whether or not the Realistic Mathematic Education (RME) approach was used with the aid of Edmodo application on problem-solving abilities in the arithmetic sequence and series material in class X SMK Negeri 1 Sindang. The type of research method used is the experimental method, with normality test and one-sample t-test. The test site was conducted at SMK Negeri 1 Sindang. Sampling was done by using the Cluster Random Sampling technique by drawing, so that the sample from this study was class X TKJ 2. After the students carried out the learning process by applying the Realistic Mathematics Education (RME) approach assisted by Edmodo application, the learning outcomes of students' mathematical problem solving abilities were obtained. with a maximum score of 92 and a minimum score of 0 with an average score of 53.83. Because $\mathrm{t}$ count $=3.13$ is greater than table $=$ 1.69 then reject, meaning that the use of the Realistic Mathematics Education (RME) approach assisted by Edmodo application is effective in achieving the target of students' mathematical problem solving abilities in arithmetic sequences and series material.
\end{abstract}

Keywords: Realistic Mathematics Education, Effectiveness, problem solving ability, edmodo application

\begin{abstract}
Abstrak
Kemampuan pemecahan masalah khususnya dalam pelajaran matematika sangat diperlukan oleh siswa. Kenyataan di lapangan menunjukkan bahwa kemampuan pemecahan masalah matematis siswa masih rendah. Upaya untuk mengatasi masalah tersebut salah satunya dengan menerapkan pendekatan Realistic Mathematics Education (RME) berbantuan Aplikasi Edmodo. Tujuan penelitian adalah untuk mengetahui efektif atau tidaknya penggunaan pendekatan Realistic Mathematic Education (RME) berbantuan aplikasi Edmodo terhadap kemampuan pemecahan masalah pada materi barisan dan deret aritmatika di kelas $\mathrm{X}$ SMK Negeri 1 Sindang. Jenis metode penelitian yang digunakan adalah metode eksperimen, dengan uji normalitas dan uji t-satu sampel. Tempat pengujian dilakukan di SMK Negeri 1 Sindang. Pengambilan sampel dilakukan dengan teknik Cluster Random Sampling dengan cara pengundian, sehingga diperoleh sampel dari penelitian ini adalah kelas X TKJ 2. Setelah siswa melakukan proses pembelajaran dengan menerapkan pendekatan Realistic Mathematics Education (RME) berbantuan Aplikasi Edmodo diperoleh hasil belajar terhadap kemampuan pemecahan masalah matematis siswa dengan skor maksimum 92 dan skor minimum 0 dengan rerata skor 53,83. Karena t hitung = 3,13 lebih besar dari t tabel =1,69 maka tolak $H_{o}$, artinya penggunaan pendekatan Realistic Mathematics Education (RME) berbantuan Aplikasi Edmodo efektif untuk mencapai target kemampuan pemecahan masalah matematis siswa pada materi barisan dan deret aritmatika.
\end{abstract}


Kata Kunci: Realistic Matematics Education, Efektivitas, kemampuan pemecahan masalah, aplikasi edmodo

\section{Pendahuluan}

Pemecahan masalah merupakan salah satu kemampuan yang harus dikuasai oleh siswa setelah belajar matematika (Ahmad \& Asmaidah 2018, Mulyati 2016). Kemampuan ini sangat diperlukan siswa karena, berkaitan dengan kebutuhan siswa untuk memecahkan masalah yang dihadapinya dalam kehidupan sehari-hari serta mampu mengembangkan diri mereka sendiri. Selain itu menurut Resmi kemampuan pemecahan masalah merupakan salah satu kemampuan penting yang harus dimiliki siswa. (Putra, dkk., 2018) Hal ini selaras dengan NCTM yang menyatakan pentingnya kemampuan pemecahan masalah matematika dalam mengembangkan pengetahuan matematika yang dimiliki (Cahyani \& Setyawati 2016, Mulyati 2016, Nurfatanah dan Rusmono 2018, Silviyani 2020). Oleh karena itu, kemampuan pemecahan masalah menjadi tujuan umum pembelajaran matematika serta setiap siswa harus memilikinya.

Dalam kenyataannya, kemampuan pemecahan masalah siswa pada saat ini masih rendah (Aceh \& Sapnaranda 2016, Nurafifah et al 2016). Menurut lembaga survey TIMSS (2015), Indonesia berada di peringkat 44 dari 49 negara dengan rata-rata skor 397 di bawah rata-rata skor internasional yakni 500 (Syamsul Hadi dan Novaliyosi 2019). Berdasarkan hasil survey TIMSS (2015) yang mengujikan aspek pemecahan masalah matematis menunjukkan bahwa rata-rata skor kemampuan matematika siswa Indonesia masih di bawah rata-rata skor internasional (Silviyani, 2020). Sejalan dengan itu menurut hasil pengamatan pada tanggal 13 bulan April tahun 2020 di SMK Negeri 1 Sindang, khususnya kelas X TKJ terdapat gambaran bahwa kemampuan pemecahan masalah matematika siswa belum seperti yang diharapkan. Misalnya kemampuan siswa dalam merencanakan masalah masih rendah, masih banyak siswa yang kebingungan dan keliru ketika menggunakan rumus untuk menghitung suatu permasalahan dalam soal cerita. Kemampuan siswa dalam menafsirkan solusi juga masih rendah karena siswa belum terbiasa menyimpulkan hasil akhir penyelesaian masalah, hanya menuliskan hasil akhir menggunakan angka. Hal tersebut dapat dibuktikan dengan melihat nilai ulangan harian matematika siswa yang dipaparkan pada tabel berikut.

Tabel 1. Data Ketuntasan Hasil Belajar Matematika Siswa Sebelum Penelitian

\begin{tabular}{ccccccc}
\hline \multirow{2}{*}{ KKM } & \multirow{2}{*}{ Kelas } & Jumlah & \multicolumn{2}{c}{ Siswa Tuntas } & \multicolumn{2}{c}{ Siswa Belum Tuntas } \\
Siswa & Jumlah & Presentase & Jumlah & Presentase \\
\hline 75 & X TKJ 2 & 36 & 13 & $36,11 \%$ & 23 & $63,89 \%$ \\
\hline
\end{tabular}

Sumber : Dokumentasi hasil ulangan harian matematika siswa kelas X TKJ 2 
Tabel 1 menunjukkan bahwa presentase ketuntasan hasil belajar siswa pada kelas X TKJ 2 SMK Negeri 1 Sindang masih rendah yaitu sebesar 36,11\%. Depdiknas (Annisa, 2016) menyatakan bahwa pembelajaran dikatakan berhasil apabila telah memenuhi kriteria ketuntasan klasikal sebesar $\geq 75 \%$ dari jumlah siswa. Proses pembelajaran yang diharapkan adalah memberikan kesempatan sebesar-besarnya kepada siswa untuk berpartisipasi secara aktif dan mampu meningkatkan pemahaman siswa tentang apa yang dipelajari sehingga pembelajaran menjadi lebih bermakna (Annisa, 2016).

Menurut Rochmad (Denni, 2019) komponen- komponen indikator efektif dapat berbeda-beda antara penelitian satu dangan lainnya. Bergantung pada pendefinisian efektif dalam penelitian tersebut. Hal ini selaras dengan pendapat Senjaya (Denni, 2019) sebuah perlakuan dikatakan efektif jika setelah perlakuan dilaksanakan rerata hasil perlakuan mencapai rerata skor/ nilai minimal yang ditargetkan. Senada dengan pendapat tersebut Dwiyani dan Utami (Denni, 2019) menyatakan suatu model pembelajaran dikatakan efektif jika lebih dari $70 \%$ nilai siswa telah berhasil mencapai nilai KKM. Dalam penelitian ini, peneliti mendefinisikan pembelajaran berkriteria efektif jika rerata nilai siswa telah berhasil mencapai nilai KKM yang telah ditetapkan oleh sekolah yaitu 75 (Ismunandar, 2019).

Menurut pendapat Hanny (2010) rendahnya kemampuan matematika siswa disebabkan oleh beberapa faktor yaitu materi pelajaran yang masih bersifat abstrak dan kurang menarik dikarenakan kurangnya contoh yang diaplikasikan dalam kehidupan sehari-hari, metode pengajaran matematika yang terpusat pada guru sementara siswa cenderung pasif sehingga tidak mempunyai kesempatan berfikir tentang matematika, serta pembelajaran matematika masih menggunakan pendekatan latihan dengan mengembangkan kemampuan pikiran melalui latihan berulang keterampilan berhitung dan meminta peserta didik menghafal langkah atau rumus-rumus (Fitriana, 2010) sejalan dengan pendapat Shefira (2018) faktor penyebab siswa mengalami kesulitan dalam pemecahan masalah matematika dapat berasal dari dalam dirinya sendiri (internal) maupun dari luar (eksternal). Faktor yang berasal dari dalam (internal) di antaranya yaitu kepercayaan diri siswa, kebiasaan belajar, kesiapan siswa (baik fisik, psikis, maupun penguasaan materi matematika) dan kurangnya minat serta motivasi siswa untuk belajar. Sedangkan faktor yang berasal dari luar (eksternal) antara lain hal-hal yang berkaitan dengan lingkungan sekolah (sikap guru, cara mengajar, situasi sosial, ruang belajar, dan 
waktu belajar), situasi dalam keluarga (sikap orang tua), kualitas pembelajaran, fasilitas pembelajaran, dan lingkungan social (Salsabila, 2018).

Berdasarkan pendapat di atas dapat disimpulkan bahwa penyebab kesulitan pemecahan masalah matematika antara lain guru kurang melibatkan siswa dalam proses pembelajaran, kurangnya model pembelajaran yang mampu menjadi stimulus dalam mengembangkan kemampuan pemecahan masalah matematika dalam memotivasi siswa untuk mengemukakan ide dan pendapat mereka, kurangnya pemahaman siswa terhadap materi yang di ajarkan oleh guru karena pembelajaran yang disajikan guru masih menggunakan pembelajaran langsung yang kurang menarik serta kurangnya kreativitas guru dalam memanfaatkan media pembelajaran dan bahkan para siswa masih enggan untuk bertanya pada guru jika mereka belum paham terhadap materi yang disajikan guru.

Terlihat dari setiap penjelasan di atas salah satu cara yang dapat digunakan untuk mencapai target efektifitas kemampuan pemecahan masalah matematika yaitu dengan menggunakan Pendekatan Realistik Matematik atau lebih dikenal dengan RME. berdasarkan hasil penelitian yang dilakukan oleh Miftahul Khoiriyah (2018) berdasarkan hasil penelitian dan pembahasan, dapat ditarik kesimpulan bahwa penggunaan pendekatan Realistic Mathematic Education (RME) merupakan salah satu solusi untuk dapat meningkatkan kemampuan pemecahan masalah matematis materi persamaan kuadrat siswa kelas X SMA Negeri 1 Angkola Selatan (Selatan \& Khoiriyah, 2018), dan menurut penelitian yang dilakukan oleh Sri Susanti (2018) dari hasil penelitian diperoleh bahwa model pembelajaran Realistic Mathematic Education (RME) dapat memberikan pengaruh yang signifikan terhadap kemampuan pemecahan masalah matematika siswa, kemampuan komunikasi matematis yang diajarkan menggunakan model Realistic Mathematic Education (RME) lebih tinggi daripada kemampuan pemecahan masalah matematika siswa yang diajarkan menggunakan model pembelajaran ekspositori. (Susanti \& Nurfitriyanti 2018). Dengan demikian penggunaan RME perlu diterapkan saat proses pembelajaran untuk mencapai hasil belajar siswa yang memenuhi standar minimal ketubtasan belajar.

Realistic Mathematic Education (RME) merupakan pendekatan yang menggunakan dunia nyata untuk memahami dan memecahkan masalah (Ismunandar, dkk., 2020). Penggunaan masalah yang realistis ini bertujuan untuk menunjukkan bahwa matematika hampir sama dengan kehidupan sehari-hari siswa (Ilma \& Putri, 2020). Berdasarkan dua pendapat di atas, RME merupakan pendekatan yang mengkaitkan dunia nyata ke dalam proses pembelajaran matematika. 
Di zaman sekarang ini, banyak media yang menawarkan aplikasi-aplikasi online yang digunakan untuk mendukung pembelajaran di luar kelas terlebih pada saat pandemi wabah virus Covid-19 yang beberapa bulan ini menerpah negara Indonesia dan negara lainnya sehingga proses kegiatan belajar mengajar harus dilakukan di rumah masingmasing. Salah satu media yang dapat digunakan untuk proses pembelajaran di luar kelas tersebut adalah dengan menggunakan aplikasi Edmodo. Aplikasi Edmodo ini menjadi pertimbangan bagi peneliti untuk digunakan karena memiliki keterbatasan waktu untuk mengunduh filenya. Selain itu aplikasi ini merupakan hal yang baru bagi guru di sekolah tersebut, sehingga belum ada pemanfaatan aplikasi Edmodo untuk melakukan pembelajaran di luar kelas.

Menurut Gruber (Sri 2019) Edmodo merupakan website jejaring sosial yang mirip dengan facebook namun digunakan untuk proses pembelajaran. Edmodo sering disebut sebagai facebook pendidikan karena Edmodo diperuntukkan bagi pendidik, peserta didik dan orang tua. Akan tetapi, pada penelitian ini, peneliti membatasi penggunaan Edmodo hanya diperuntukkan bagi guru dan peserta didik saja.

Menurut Al-Kathiri (Sri 2019) penggunaan Edmodo memiliki banyak tantangan dan potensi yang bagus dalam pembelajaran. Edmodo juga dilengkapi dengan berbagai macam fitur yang dapat digunakan oleh guru untuk mengunggah materi yang diajarkan, membuat kelas untuk berdiskusi, membuat quiz online dan sebagainya. Edmodo dapat membantu guru untuk memberikan materi yang diajarkan di kelas, membantu guru mengatasi waktu yang terbatas ketika melakukan diskusi latihan soal di jam pelajaran dengan memfasilitasi adanya kegiatan diskusi di luar kelas dan membantu guru untuk memantau sejauh mana proses diskusi tersebut sudah dilakukan oleh peserta didiknya (Theresia Nuhuyanan 2019).

Berdasarkan hasil penelitian yang telah dilakukan oleh Vera Dewi Kartini Ompusunggu dan Nilam Sari (2019), dapat disimpulkan bahwa penggunaan media edmodo efektif terhadap kemampuan komunikasi matematika pada matakuliah pendalaman materi matematika kelas B41 PGSD Universitas Quality, (Ompusunggu \& Sari, 2019) serta berdasarkan hasil penelitian yang dilakukan oleh Hanifah,dkk (2019) dapat disimpulkan bahwa terdapat pengaruh model pembelajaran e-learning berbantuan edmodo dengan model pembelajaran konvensional terhadap kemampuan pemecahan masalah matematis peserta didik (Hanifah et al 2019).

Berdasarkan hasil penelitian di atas, maka penulis tertarik untuk mengambil judul ,yaitu: "Efektivitas Pendekatan Realistic Mathematics Education (RME) Berbantuan 
Aplikasi Edmodo terhadap Kemampuan Pemecahan Masalah Matematis Siswa pada Materi Barisan dan Deret Aritmatika kelas X SMK Negeri 1 Sindang”.

\section{Metode Penelitian}

Penelitian ini dilaksanakan di SMK Negeri 1 Sindang yang beralamatkan di Jalan Mayor Dasuki No. 3B RT. 01 RW. 01 Desa Penganjang Kecamatan Sindang Kabupaten Indramayu Kode Pos 45211 Telp/Fax. (0234) 274949 Email: smkn1sindang@yahoo.com . Penelitian dilaksanakan di kelas X pada semester ganjil tahun 2020/2021. Populasi dalam penelitian ini adalah Kemampuan Pemecahan Masalah matematis siswa kelas X TKJ SMK Negeri 1 Sindang Semester Ganjil Tahun Pelajaran 2020/2021 yang berjumlah 141 siswa, dengan data sebagai berikut:

Tabel 2. Jumlah Siswa Kelas X TKJ SMK Negeri 1 Sindang

\begin{tabular}{lll}
\hline No. & Kelas & Jumlah \\
\hline 1. & X TKJ 1 & 34 \\
2. & X TKJ 2 & 36 \\
3. & X TKJ 3 & 35 \\
4. & X TKJ 4 & 36 \\
Jumlah & & $\mathbf{1 4 1}$ \\
\hline
\end{tabular}

Sumber: Tata Usaha SMK Negeri 1 Sindang, Januari 2020

Pengambilan sampel dilakukan dengan menggunakan Cluster Random Sampling dengan cara pengundian. Berdasarkan hasil pengundian terpilih kelas X TKJ 2 sebagai kelas eksperimen. Desain yang digunakan dalam penelitian ini adalah desain penelitian dengan uji efektivitas atau Uji T-Satu Sampel (Senjaya, 2018).

\section{$\mathbf{R}: \mathbf{T} \mathbf{O}$}

\section{Keterangan :}

R : Randomisasi Pengambilan Sampel

$\mathrm{T}$ : Perlakuan (Treatment) yaitu pendekatan RME berbantuan aplikasi Edmodo terhadap kemampuan pemecahan masalah matematis siswa pada materi barisan dan deret aritmatika

O : Observasi ( Pengumpulan data/ Posttest )

Data yang diperlukan dalam penelitian ini akan dikumpulkan dengan teknik pemberian tes kemampuan pemecahan masalah matematis siswa pada materi barisan dan deret aritmatika dalam bentuk uraian. Setelah data terkumpul, selanjutnya dilakukan 
pengolahan data, yaitu : 1) Uji normalitas dengan menggunakan uji Lilifors 2) Uji efektivitas perlakuan berdasarkan kriteria rerata target. (Senjaya, 2018)

\section{Hasil dan Pembahasan}

Berikut akan disampaikan hasil dan pembahasan pada penelitian ini.

Tabel 3. Data hasil Tes Kemampuan Pemecahan Masalah Matematis Siswa

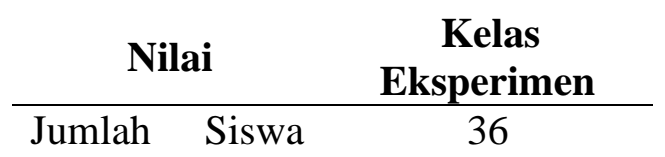

(n)

Rerata

Varians

976,31

Simpangan

31,25

Baku

Berdasarkan tabel 3 di atas, rata-rata diperoleh 53,83 varians 976,31 dan simpangan baku 31,25. Selanjutnya akan disampaikan mengenai hasil uji normalitas.

Tabel 4. Data Hasil Uji Normalitas Kemampuan Pemecahan Masalah Matematis Siswa pada Materi Barisan dan Deret Aritmatika

\begin{tabular}{ccccc}
\hline Kelas & $\boldsymbol{L}_{\boldsymbol{o}(\text { hitung })}$ & $\boldsymbol{L}_{\boldsymbol{k}(\text { tabel })}$ & $\boldsymbol{L}_{\boldsymbol{o}(\boldsymbol{h i t u n g})<\boldsymbol{L}_{\boldsymbol{k}(\text { tabel })}}$ & Keterangan \\
\hline X TKJ 2 & 0,122 & 0,148 & $0,122<0,148$ & $\begin{array}{c}\text { Berdistribusi } \\
\text { Normal }\end{array}$ \\
\hline
\end{tabular}

Uji normalitas berlaku untuk prasyarat uji parametrik dan mengetahui apakah sampel diambil dari populasi berdistribusi normal atau tidak berdistribusi normal. Berdasarkan tabel di atas dijelaskan bahwa pada kelas X TKJ 2 diperoleh $L_{o}=0,122$ dan $L_{k}=0,148$ karena $L_{o}<L_{k}$ maka dapat disimpulkan bahwa sampel diambil dari populasi yang berdistribusi normal.

Tabel 5. Data Hasil Uji t-satu sampel Kemampuan Pemecahan Masalah Matematis Siswa pada Materi Barisan dan Deret Aritmatika

\begin{tabular}{ccccc}
\hline $\mathbf{N}$ & $\boldsymbol{\mu}_{\boldsymbol{o}}$ & $\boldsymbol{\mu}_{\boldsymbol{k}}$ & $\boldsymbol{t}_{\boldsymbol{o b s}}$ & $\boldsymbol{t}_{\boldsymbol{k}}$ \\
\hline 36 & 53,83 & 37,5 & 3,13 & 1,69 \\
\hline
\end{tabular}

Berdasarkan data di atas, dapat dijelaskan bahwa rerata skor kemampuan pemecahan masalah matematis siswa pada materi barisan dan deret aritmatika adalah 53,83 dengan kriteria efektif yaitu 37,5. Diperoleh $t_{\text {obs }}=3,13$ dan $t_{k}=1,69$.

Karena $t_{o b s}>t_{k}$ maka tolak $\mathrm{H}_{o}$, artinya pendekatan Realistic Mathematics Education (RME) berbantuan Aplikasi Edmodo efektif untuk mencapai target 
kemampuan pemecahan masalah matematis siswa pada materi barisan dan deret aritmatika.

Hasil uji efektivitas pendekatan Realistic Mathematics Education (RME) berbantuan Aplikasi Edmodo pada Materi Barisan dan Deret Aritmatika menggunakan uji t-satu sampel, diperoleh $t_{o b s}=3,13$ dan $t_{k}=1,69$ karena $t_{o b s}>t_{k}$ maka tolak $H_{o}$ artinya pendekatan Realistic Mathematics Education (RME) berbantuan Aplikasi Edmodo efektif untuk mencapai target kemampuan pemecahan masalah matematis siswa pada materi barisan dan deret aritmatika.

Berdasarkan uraian di atas dapat disimpulkan bahwa penerapan pendekatan Realistic Mathematics Education (RME) berbantuan Aplikasi Edmodo efektif untuk membantu kemampuan pemecahan masalah matematis siswa pada materi barisan dan deret aritmatika.

Hal ini selaras dengan penelitian yang dilakukan oleh Nida Zarmita dan Hazami diperoleh bahwa hasil belajar siswa melalui pendekatan RME pada materi perkalian di kelas IV MIN Tungkob Aceh Besar adalah tuntas dengan persentase 83,8\% dari 37 orang siswa (Jarmita \& Hazami, 2013) dan penelitian yang dilakukan oleh Agnes (2019) dapat disimpulkan bahwa keefektifan pembelajaran Matematika dengan memanfaatkan aplikasi Edmodo sebagai media bantu diskusi dilihat dari hasil belajar peserta didik sudah sangat efektif dan termasuk dalam kriteria efektivitas sangat tinggi dengan persentase sebesar 84\%. Selain itu, pembelajaran Matematika dengan memanfaatkan aplikasi Edmodo sebagai media bantu diskusi tidak mengganggu hasil belajar peserta didik dikarenakan persentase ketuntasan hasil belajar peserta didik sudah baik yaitu sebesar 92\% (Theresia, 2019).

\section{Kesimpulan}

Berdasarkan penelitian yang telah dilakukan dan analisis data menggunakan PESTRIPP versi 0618, kesimpulan hasil penelitian ini adalah pendekatan RME berbantuan aplikasi Edmodo efektif untuk membantu siswa mencapai kemampuan pemecahan masalah matematis di Kelas X TKJ 2 materi barisan dan deret aritmatika. Hal ini dapat dilihat dari hasil belajar siswa yang melebihi KKM, uji t-satu sampel menujukkan bahwa terlihat sig=0,05. Artinya tolak H0 dan terima Ha . Pada uji banding to $>$ tk, artinya pendekatan RME berbantuan aplikasi Edmodo pada kelas eksperimen efektif terhadap kemampuan pemecahan masalah matematis siswa, hal ini dikarenakan 
nilai rata - rata hasil belajar kelas ekperimen melebihi KKM yang ditetapkan oleh sekolah.

Berdasarkan kesimpulan dari hasil penelitian diatas, maka yang menjadikan saran bagi penulis adalah sebagai berikut : (1) Kepada Siswa, diharapkan dapat lebih giat lagi dalam belajar dan dapat memperbaiki cara belajarnya dalam menerima pelajaran disekolah maupun dirumah, meskipun pemerintah mewajibkan untuk belajar dirumah karena covid-19 namun, semangat belajar tidak boleh kendor. Siswa harus lebih konsentrasi dan aktif dalam proses belajar mengajar, seperti aktif dalam menemukan halhal baru, pengetahuan baru, dan aktif untuk bertanya serta banyak mengerjakan Latihanlatihan untuk meningkatkan kemampuan pemecahan masalah matematis siswa (2) Kepada guru matematika, diharapkan mampu untuk memilih dan menerapkan serta menyesuaikan pendekatan pembelajaran yang sesuai dengan materi yang akan diajarkan agar siswa lebih aktif dan mudah dalam memahami materi yang dijelaskan (3) Kepada kepala sekolah, diharapkan dapat mendorong dan membina para guru untuk melaksanakan proses pembelajaran dengan baik sehingga proses pembelajaran dapat tercapai sesuai tujuan pembelajaran (4) Kepada peneliti lainnya, diharapkan dapat melanjutkan penelitian ini dengan melihat sisi lain dari masalah yang sudah ada agar kemampuan matematika lainnya dapat ditingkatkan.

\section{Pustaka}

Aceh, B., \& Sapnaranda, S. (2016). Peningkatan Kemampuan Pemecahan Masalah Matematis Siswa melalui Model Pembelajaran berbasis Masalah pada Materi Sistem Persamaan Linear Dua Variabel di Kelas VIII MTsN COT Gleumpang. Fakultas Tarbiyah Dan Keguruan Universitas Islam Negeri Ar-Raniry Darussalam - Banda Aceh 2017/1438 H, 170205043, 1-127.

Ahmad, M., \& Asmaidah, S. (2018). Pengembangan Perangkat Pembelajaran Matematika Realistik Untuk Membelajarkan Kemampuan Pemecahan Masalah Matematika Siswa Smp. Mosharafa: Jurnal Pendidikan Matematika, 6(3), 373-384. https://doi.org/10.31980/mosharafa.v6i3.326

Annisa, U. (2016). Penerapan Model Pembelajaran Realistic Mathematic Education (Rme) Untuk Meningkatkan Aktivitas Dan Hasil Belajar Matematika Siswa Kelas Iv S D Negeri 1 Tempuran. http://digilib.unila.ac.id/22366/3/SKRIPSI TANPA BAB PEMBAHASAN.pdf

Cahyani, H., \& Setyawati, R. W. (2016). Pentingnya Peningkatan Kemampuan Pemecahan Masalah Melalui PBL untuk Mempersiapkan Generasi Unggul Menghadapi MEA. PRISMA, Prosiding Seminar Nasional Matematika, 151-160.

Fitriana, H. (2010). Pengaruh Pendekatan Pendidikan Matematika Realistik Terhadap 
Kemampuan Pemecahan Masalah Matematika Siswa. Evolution, 1-14.

Hanifah, H., Supriadi, N., \& Widyastuti, R. (2019). Pengaruh Model Pembelajaran Elearning Berbantuan Media Pembelajaran Edmodo Terhadap Kemampuan Pemecahan Masalah Matematis Peserta Didik. NUMERICAL: Jurnal Matematika Dan Pendidikan Matematika, 3(1), 31-42. https://doi.org/10.25217/numerical.v3i1.453

Ilma, R., \& Putri, I. (2020). MGMP optimization in developing teacher professionalism in developing HOTS problems based on RME approach MGMP optimization in developing teacher professionalism in developing HOTS problems based on RME approach. https://doi.org/10.1088/1742-6596/1657/1/012022

Ismunandar, D. (2019). Efektifitas Model Discovery Learning Di Kelas Viii Materi Relasi Dan Fungsi. Journal Universitas Wiralodra, 62-72.

Ismunandar, D., Gunadi, F., Taufan, M., Mulyana, D., \& Runisah. (2020). Creative thinking skill of students through realistic mathematics education approach. https://doi.org/10.1088/1742-6596/1657/1/012054

Jarmita, N., \& Hazami, H. (2013). Ketuntasan Hasil Belajar Siswa Melalui Pendekatan Realistic Mathematics Education (Rme) Pada Materi Perkalian. Jurnal Ilmiah Didaktika, 13(2), 212-222. https://doi.org/10.22373/jid.v13i2.474

Mulyati, T. (2016). Kemampuan Pemecahan Masalah Matematis Siswa Sekolah Dasar (Mathematical Problem Solving Ability of Elementary School Students). EDUHUMANIORA: Jurnal Pendidikan Dasar, 3(2), 1-20.

Nurafifah, L., Nurlaelah, E., \& Usdiyana, D. (2016). Model Pembelajaran Osborn Untuk Meningkatkan Kemampuan Pemecahan Masalah Matematis Siswa. M A T H L I N E: Jurnal Matematika Dan Pendidikan Matematika, 1(2), 93-102. https://doi.org/10.31943/mathline.v1i2.21

Nurfatanah, Rusmono, N. (2018). Kemampuan pemecahan masalah matematika siswa sekolah dasar. Dasar, Pendidikan Universitas, Pascasarjana Jakarta, Negeri, 546551.

Ompusunggu, V. D. K., \& Sari, N. (2019). Efektifitas Penggunaan E-Learning Berbasis Edmodo Terhadap Kemampuan Komunikasi Matematika. Jurnal Curere, 3(2), 5866. https://doi.org/10.36764/jc.v3i2.250

Putra, H. D., Thahiram, N. F., Ganiati, M., \& Nuryana, D. (2018). Kemampuan Pemecahan Masalah Matematis Siswa SMP pada Materi Bangun Ruang. JIPM $\begin{array}{llll}\text { (Jurnal Ilmiah Pendidikan } & \text { Matematika), }\end{array}$ https://doi.org/10.25273/jipm.v6i2.2007

Salsabila, S. (2018). Pengaruh Model Pembelajaran VAK Terhadap Kemampuan Pemecahan Masalah Matematis Kelas III SD It At-Taufiq Al-Islamy Tasikmalaya Skripsi.

Selatan, A., \& Khoiriyah, M. (2018). Efektivitas Pendekatan Realistic Mathematic Education ( RME ) Terhadap Kemampuan Pemecahan Masalah Matematis Siswa 
Di Sma Negeri 1. 1(2), 54-59.

Silviyani, D. (2020). Peningkatan Kemampuan Pemecahan Masalah Matematis Siswa Melalui Metode TGT berbasis media pembelajaran Interaktif. In skripsi. Wiralodra Indramayu.

Susanti, S., \& Nurfitriyanti, M. (2018). Pengaruh Model Realistic Mathematics Education (RME) Terhadap Kemampuan Pemecahan Masalah Matematika Pada Siswa Kelas VII SMPN 154 Jakarta. JKPM (Jurnal Kajian Pendidikan Matematika), 3(2), 115. https://doi.org/10.30998/jkpm.v3i2.2260

Theresia Nuhuyanan, A. (2019). keefektifan pembelajaran matematika dengan memanfaatkan aplikasi edmodo sebagai media bantu diskusi kelas xi mipa 4 sma negeri 8 yogyakarta tahun ajaran 2018/2019. Fakultas Keguruan Dan Ilmu Pendidikan Universitas Sanata Dharma Yogyakarta 2019, 2.

Senjaya, Juhana, A. 2018.Langkah-langkah analisis statistik. Yogyakarta: K-Media . (2018). PESTRIPP(versi0618) 
